\title{
REGIONAL DEVELOPMENT BETWEEN COHESION AND COMPETITION - CURRENT THESES AND FIELDS OF ACTION
}

\author{
Martin Heintel, Alice Wanner, Norbert Weixlbaumer ${ }^{1}$
}

Received 4 September 2017; Accepted 19 January 2018

\begin{abstract}
This contribution discusses regional development drawing on the EU member state Austria as an example. The crosscutting theme is illustrated from initial positioning through to relevant fields of action. In doing so, the way forward is seen as a process and those who accompany it are seen as the ones responsible for its implementation. Responsibilities are identified along theses. These are formed in the context of demographic change, mobility, energy, regional public services, residential development, cooperation and governance processes. Fields of action are discussed in accordance with the developed theses.
\end{abstract}

Key words: regional development, rural development, sustainable land management, European Union, cohesion policy, peripheral rural areas.

\section{Introduction}

Regional development is a crosscutting theme that is addressed on various levels such as public administration, service facilities, and bottom-up processes. Its effectiveness lies on multiple levels of scale ranging from EU set goals to local projects. The quality and length of the development processes is varied and context bound. Usually the process is guided through governance arrangements (see Heintel, 2006). "Differences in the performance of institutions play a central role in explaining patterns of local and regional growth"(see Pike et al., 2017: 52).

The initial situation for rural development is increasingly being led by competing steering approaches. These approaches are "Equivalence" and "Competition". Simultaneously, new key objectives are emerging: sustainable resource management and participation.

The aim of this contribution is to stake out the framework of rural peripheral regions with their partially contradicting dynamics and derive future oriented theses from this. The main focus is to determine which fields of action for future development of rural areas are most important for regional policy. It is an important regional and sociopolitical discourse as it addresses structural

\footnotetext{
1 Prof. Martin Heintel, PhD., martin.heintel@univie.ac.at, Department of Geography and Regional Research, University of Vienna, Universitätsstraße 7/5, AT-1010 Vienna; Alice Wanner, M.A., alice.wanner@boku.ac.at, Institute of Landscape Development, Recreation and Conservation Planning, University of Natural Resources and Life Sciences, Vienna, Peter-Jordan-Straße 65, AT-1180 Vienna; Prof. Norbert Weixlbaumer, PhD., norbert.weixlbaumer@univie.ac.at, Department of Geography and Regional Research, University of Vienna, Universitätsstraße 7/5, AT-1010 Vienna
} 
requirements and courses of action which carry long-term regional development impacts for rural areas within Europe.

Furthermore, the discussions on courses of action concerning sociopolitical handling of resources are to be brought forward. The described fields of action are founded in numerous projects and current debates in applied research. They specifically concern topics of demographic change, living conditions, financial equalization, socioeconomic prerequisites of rural peripheries and large-scale protected areas as potentials in regional development (see Hammer, Mose, Siegrist \& Weixlbaumer, 2016; Heintel, Speringer, Bauer \& Schnelzer, 2016).

\section{Initial Positioning}

Rural regions are diverse. Rural regions in proximity to cities differ from rural peripheral regions in the different conditions set and interrelation contexts present (see Gagliardi \& Percoco, 2017). There is no uniform narrative to clearly describe rural change. Brown \& Schucksmith show several narratives to illustrate rural or regional development comprehensively. Therefore, "(a) an agri-centric narrative, (b) an urban-rural access narrative, (c) a competitive and (d) a narrative of society-nature interrelationships" (Brown \& Schucksmith, 2016: 183) are jointly responsible for visualizing change at a regional level.

Regional development is a crosscutting theme aiming to bring together sector politics and society's activities in the best possible way in areas affected by both. This means that desired (economic, social or aesthetic) organization and/or a positive (economic, social) change (development) is achieved (Heintel 2005: 23). It makes clear that the terms "regional development" and "regional policy" are not used distinctively enough.

The 1990s saw regional developments seeking to spread balance as a reaction to regional disparities. These days' argumentations are aligned with improving economic and living conditions, aiming at cohesion. They are determined by the presentation of sustainable development processes and the flexible guiding principle of equal living conditions. Generally speaking, these are founded in state and national level planning regulations.

Optimizing regional development is in persistent need of communication between different administrative levels, coordination and reflective discussions among various perspectives and interest groups. Harmonizing the communication levels is a necessary prerequisite. Therefore, the challenge is in interlinking perspectives of regional development between the European Union, national level and state level responsibilities, and (specific) regional interests.

Space is a dimension constructed of individual and social actions. The subject of planning (in a further sense also analysis and evaluation) is not space itself. Moreover, it is the relations and conditions under which the economic, social, technical and ecological systems function. Society and space stand in a complex and dynamic relation to each other (Schindegger, 1999: 25). This dynamic is in constant need of renegotiation, especially in areas which have recently been affected by negative dynamics.

In this context, disadvantages can be described, similarly to social inequality, as the unequal distribution of material and immaterial resources in a society and the resulting disparities in opportunities to partake in these. The definition is descriptive and normative in character. Under normative examination contradictions usually arise.

Addressing the underlying theme for example: a peripheral location is rated differently by daily commuters than by secondary residence owners. Single standing private homes are seen as assets for realty owners. For the communities, these houses cause enormous costs and unnecessarily large use of space for the community. A further example: the percentage of nonAustrian population in rural peripheral areas is relatively small in relation to urban conglomerations. If a normative statement was made in this instance, it could be very contradictory depending on political ideology or opinion. Immigration could be seen as a development potential (e.g. compensation for negative population growth) or as a hindrance (e.g. "cost factor", rising regional unemployment) for rural peripheral areas. 
The primary focus is not on demographic data of the "counted humans" or the single infrastructure establishments. In regional development the focus is on steering mechanisms, tax claim, possible cooperation and ongoing aims and levels of action. "Steuern - steuern!" (Translation: Steer-taxes!) is a phrase often used as a mission statement on a communal level.

In the Work Program (2013-2018) in the chapter "Future of rural areas" (Republik Österreich, 2013: 20) the Austrian government has set the following goals: The living and economic locations in rural areas are to be secured and developed.

Aims:

- Increase purchasing power

- Create employment opportunities, bring work to the people, create qualified employees

- Secure accessibility

- Research and Innovation campaigns for rural areas

- Secure equal public service access and security

"Challenges: The Austrian government will set a focus on strengthening the rural areas, in which 66 percent of the population is currently living. ${ }^{2}$ In future development, the goal is to bring employment to the people and to secure equal public services in rural areas. The national government will commission the development of a Master Plan for Rural Areas."

In Germany, the current recommendations in this context are to aim for „Equality“ as a national goal, simultaneously also developing a "contemporary understanding of public services" (see Akademie für Raumforschung und Landesplanung, 2016).

Cohesion-oriented regional policies are in rivalry to competition-oriented regional policies, which aim at strengthening already dominant regions to make them more competitive on the global market (see European Union, 2017; Nosek, 2017). To date, competitive oriented policies have not had polarizing effects on the Austrian society. There are some indications, however, that the aforementioned "equality" is being questioned. A close watch should be kept on these conflicting forces in future.

This discussion is even being picked-up on by the OECD. While using the opportunity to discuss multi-level governance reforms (see OECD, 2017), a simultaneous target of increasing competition between regions of the EU territory for effective resource use is being formed. "OECD work on regional development recognises that a new approach to regional development is emerging; one that promises more effective use of public resources and significantly better policy outcomes. This involves a shift away from redistribution and subsidies for lagging regions in favour of measures to increase the competitiveness of all regions. Some key features of this new approach to regional development include: a development strategy that covers a wide range of direct and indirect factors that affect the performance of local firms; a focus on regional specific assets, and less on top-down investments and transfers; an emphasis on opportunity rather than on disadvantage or need for support; a collective/negotiated governance approach involving national, regional and local government plus other stakeholders, with the central government taking a less dominant role." (OECD, 2016).

In literature (see Reiner, Gassler \& Sardadvar, 2015: 170), this topic has already been mentioned in the beginning of the 1990s in connection with EU- pre-accession preparations in Austria. Around 1990, a paradigm shift in regional policy emerged and was accelerated through EU- requirements. The traditional balance orientation of regional policy (reduction of regional disparities) made way for supply-driven or competition-oriented programs and according measures (see Zschiedrich, 2008). These discussions also occurred in Germany and to a lesser extent in Scandinavian states since the disparities within these countries were more prominent than currently in Austria.

Reiner et al. (2015: 161) explains that providing infrastructure services by the state have long been a central part of the European welfare state. Crouch (2008) expands on this statement

\footnotetext{
${ }^{2}$ Municipalities with a population greater than 5.000 are defined as "urban".
} 
saying that this was an important part of democratizing society. After all it was about compromising between the egalitarian welfare state of democracy and the inequalities of capitalism. This compromise in the infrastructure sector is put into question through the tirade of liberalization, deregulation and privatization.

Aiming for a societal consensus, which scenario will be catered to how, can also be seen as a foundation for fiscal equalization negotiations. Regardless of the objectives, the expense factor wins out, to some extent due to the debt some municipalities find themselves in. The question what should and what will not be funded in future is reinforced.

As a result some contradictions, trends and fields of action along with theses are drawn up, that will hopefully lead to new reflection and discussion. They are based on recent research of the Department of Geography and Regional Research at the University of Vienna ${ }^{3}$. It is an issue that can be expanded on, on the one hand, and can lead to deeper processing in respective contexts on the other. Some aspects have been drawn up along theses and linked to investigated regions. They are being examined in accordance with the methodology of intervention research (see Krainer \& Lerchster, 2012; Lerchster \& Krainer, 2016). The premise for this research is future challenges in regional development of rural areas and future courses of action.

\section{Field of action: Solidarity versus Individuality}

The European Union seeks to be mutually supportive. The basis for achieving balance and stability are the regional policies and transfer effects. It is similar in fiscal equalization. In this situation, it is about securing infrastructure on the one hand and scaling competences according to municipality size on the other. Some supra-regional responsibilities correspond to the principle of varied centrality of locations.

As mentioned previously, the general consensus of "equal basic services" reared as a guiding principle, is also overridden by market mechanism and competition measures. The basic consensus of a solidly united society is lost when the bond to the region of origin is lost. With every emigration or loss of a generation, which was residing in an area, this issue becomes more pressing.

The thesis is that as soon as the bond to a region is lost, solidarity diminishes and individuality increases. When the connections deteriorate, structures break down and links are lost. To exaggerate: An urban resident no longer understands the countryside. It is a quiet and creeping change, but it is already being seen here and there. Rural areas need to become more "urban", to secure their connectivity to central areas.

\section{Field of action: Urban versus Rural}

„Stadt und Land reicht euch die Hand!“ (Translation: "City and Country shake hands!") is a quote often used by municipal and city associations that indicates that urban-rural-linkages are not always easy. In international European comparison, Austria has long been exemplary in regional development initiatives; especially for rural peripheral regions. Much of the know-how has been exported to Germany as well as into new member states of the European Union for pre-accession aid. In Austria, there is a need to advance development of urban regions and urban - rural relationships. For urban regions, Germany can be drawn upon as a role model with a multitude of cooperation models, internal organization and political legitimacy. The Austrian Conference on Spatial Planning (ÖROK) has recently pulled this topic into the foreground (see Humer, 2017; ÖROK, 2016).

This relationship needs to be reflected upon in the context of competition and cohesion. Cities are hubs of the global economy and generally speaking growth regions. Nowadays, we are also living in intertwined areas with collateral dependencies (see Ward \& Brown, 2009). Organizing and steering these regions is a task that falls upon planners and politicians. All measures that effect regional development are to be examined critically. Housing subsidies, commuter

\footnotetext{
${ }^{3}$ http://geographie.univie.ac.at (29.08.2017)
} 
allowance, settlement policies, parking management, public transport subsidies are all publically funded steering mechanisms.

Thesis: Even a task oriented fiscal equalization must be evaluated in the context of cooperation between peripheral and agglomeration regions.

\section{Field of action: Multi locality versus spatial ties}

Regional bonds have drastically changed over the past 25 years. Lifestyles and cycles, family organization and the participation in education possibilities and measures along with the labor market itself are responsible for this shift. "Modern Movement" describes the rising mobility between locations and the shifts of reorientation in private and professional life. All of these attributes encourage multi-locality. Multi-locality is a trend that is only gradually being noticed in Austria. However, nearly one million people in Austria are living multi-locally, from academic elites to unskilled laborers.

What is the reaction to this trend? So far it has been creative but ultimately insufficient. Creative for example, when a craftsman's workshop is set up and maintained in the periphery, but at the same time also rents an apartment in the city for its installation workers. Business is located in two places. The business site in the periphery is secured.

The country side needs to offer opportunity for the "multi-local" so the bond to the region of origin is not lost. The temporary, sometimes limited, life situation needs to be appreciated. "Crossing" is needed, lateral thinking and progress instead of being caught in the past. "Choreographing the context" (see below) can be seen as a step forward for rural peripheral regions. In doing so, an understanding must emerge, that society is becoming more urbanized. New forms of simultaneity can be made useful in society.

Now, propositions can be made for those in temporary absence in acceptance and appreciation of this coexistence. Reciprocally, attributes are becoming more widespread in urban areas that are categorized as rural. Open doors of ground floor establishments, tables in front of the door, communicating in public spaces, mixing functions of purchasing and pub etc., organized ties in neighborhoods, networking through mutual experiences - all these things are trending in cities.

Thesis: Organizing social systems in the place of origin with a possibility of incorporating multilocals creates a bond. „Wenn einer von uns Matura macht, können wir die schwarze Fahne hissen, dann ist er weg, sie sind für das Dorfleben verloren!" (Translation: "When one of our own finishes school, we can raise a black flag. He is gone and lost to village life. $)^{4}$ Is common in this context, but diverts from seeing bonding possibilities. Additionally, education is not appreciated and is even connected to the "black flag" metaphor.

\section{Field of action: Immigration versus Emigration}

This current and politically normative connotative topic - regardless of underlying humanitarian motives - can be discussed along two lines: Immigration, in particular, a demographic one as a chance or as a threat, especially concerning the labor market.

Mentioning this topic at this point should assure its position in general perception. Solidarity in society is not just a question of urban or rural, but among different regions of origin. Shaping and steering these will probably also be a field of action in future.

Thesis: A rising imbalance between urban and rural regions on this topic will be criticized more and more by cities in future. Solidarity in distribution and integration by and of rural regions will be demanded. Positive examples of integration in rural areas should not be concealed but brought forward.

\footnotetext{
${ }^{4}$ This quote was said by the mayor of Moschendorf (Southern Burgenland/Austria) and was captured for the ORF TV Program Thema (02.05.2016).
} 


\section{Field of action: Dismantling versus Expansion}

Dismantling or shrinking has been a "no-go" in Austrian political discourse. In direct comparison to Germany, the topic of shrinking regions in Austria has not really arrived yet. Growth is not to be questioned ideologically; moreover, it is about proactively addressing shrinking in the areas where it is irreversible.

Concerning infrastructure, Mayerhofer comes to the following conclusion: It is not advised to follow a strategy that is based on aggressive infrastructure development and aims at making one municipality more attractive than the other. It cannot be successful under the given demographic framework. It does increase location competition (in addition to slowing the shrinking process) and can have substantial financial risks for municipalities, even in infrastructure utilization (Mayerhofer, 2014: 105).

The times of competing with neighboring municipalities by constructing indoor swimming pools are long gone. There is a need for sensible governance in implementing infrastructure measures, even more so where they can be used cooperatively.

Maintaining infrastructure with non-critical utilization, the adjustment of institutions for a multiethnic and demographically aging population are just as critical as the extent of social transfers between financial feasibility through the public sector and upholding the will to live of those who predominantly pay into the public households (ÖROK, 2011: 17).

Thesis: Dismantling needs to be acceptable where alternatives are lacking. The political actors need the relief through and support from society. New forms of communication need to make communication of old taboos possible. Failing to support one's own population through evidence based development in the belief of securing one's political lifespan instead is not acceptable. Constructive handling of usually negatively connoted and emotionally laden themes is needed (see Dax, Fidlschuster, Fischer, Hiess, Oedl-Wieser \& Pfefferkorn, 2016: 77ff.).

\section{Field of action: Claims versus Reality}

The use of public infrastructure and facilities for daily life are as varied and diverse as society itself. Statistically speaking, a person goes to their district administration facilities every one and a half years. Many things are being communicated electronically. Keeping close to the population in future will be a digital affair. Overcoming distances for rarely used services become more acceptable and may even secure some locations - medical and educational basic services exempt. Banking and postal services and their local presence have changed, something that is also affecting cities.

Trends in shopping habits show a lean towards "green fields" and "roundabouts". "Geht keiner zum Wirt - dann geht er ein!" (Translation: "If nobody goes to the pub - then it will have to shut down!"): This aphorism serves as a self-reflection on one's own consumer habits and individual use of public transport. If a location or service shuts down, it is usually met with outrage.

Thesis: Rationalization overlays the debate on uncritical capacity/demand of specific infrastructure. By doing so, they remove themselves from a self-critical analysis of one's own consumer and transport choices.

\section{Field of action: Public Responsibility versus Self-Responsibility}

The St. Florian principle (Austrian: Floriani-Prinzip) or St. Florian Policy describes behavioral patterns that do not look to solve threats or dangers but rather push responsibilities onto others. More commonly in English, it is known as Nimby, the acronym for "Not in my backyard". In Austria, it used to be common to call on Saint Florian, the patron saint for averting fire or drought. Traditionally, it was spread as a devout saying, possibly from the ironically intended votive tablet concise saying: Heiliger Sankt Florian / Verschon' mein Haus / Zünd' and're an! (Translation: Holy St. Florian/Spare my house/Light somebody else's!). Another assumption is that it stemmed from a satirical song that enviers of the Salzburg cathedral, pilgrims from 
Pinzgau invented. ${ }^{5}$ It is not a Pinzgau principle but far more an Austrian phenomena to enjoy delegating responsibility onto others, especially "to Brussels", but also onto other central regions.

Thesis: Self-responsibility and commitment are worth supporting but it cannot be expected to be a sure-fire successes or that problems will be solved when the responsibility (political or legal legitimization) lie somewhere else. At the same time, there is a (international) need to have a comparative and critical reflection on subsidy mentality and their necessity (e.g. specific EUsubsidies).

\section{Field of action: Persistency versus Change}

Changes and shifts mean breaking down locked in structures and questioning the familiar. In the literature, there are currently discussions on resilience in regional development (see Lukesch 2016). Here the development cycle of regions is addressed along with the adaptability of a region to new conditions. There is a danger of staying in rigid scenarios in regions that "aren't that bad off", meaning that a region can maintain a relatively resilient state by living off the resources in the dominating system. Over the long run, this can reduce a region's adaptability by losing young workers or positions of power being blocked by the regional elite. The strategy is maintained by relying on the old instead of a rational evaluation and critical analysis.

Learning, education, qualification and coupling these shifts with work life are basics in assuring a flexible approach to change. The role of women and club structures are changing locally (how many personal unions can be found on boards?) and are important indicators for structural consolidation and permeability.

Thesis: If change cannot be introduced in municipalities/regions, then there is a high risk of remaining in locked-in structures. Selectively promoting immigration, new cooperations, bonding opportunities for emigrants etc., are to be promoted.

\section{Field of action: Cooperation versus Isolation}

Strengthening regional action levels are a development option for the future (see ÖROK, 2011; 2015). Finding structures that fit new challenges are not just an issue for rural region. Fitting structures are also being discussed anew for the growing city Vienna, as presented in a new study conducted by the Chamber of Employment (see Kammer für Arbeiter und Angestellte für Wien, 2016). The Thesis is formed that districts (the small organizational subdivisions of the city) hinder the development of the city from a high-level point of view (idib. Pg. 130). District clusters should not be a taboo topic. Two-sidedness in administration and redundancies of public infrastructure are to be critically questioned. Territorial and administrational reforms should not be a taboo topic in rural regions. The construction of regional councils and unions that have problem-solving expertise are even worth supporting in thematic and occasional appropriate situations.

Thesis: In future, there will be an increase in questions concerning cooperation and crossmunicipal organization. The reasons for this include global competition due to costs or simply because of psychological strain.

\section{Field of action: Rationality versus Emotionality}

Regional development, even development in general, always implies normative foundations, values, management and emotions along with evaluation of resources. Therein lays the danger of valuing the self-image of disadvantages very highly. Benchmarks and comparisons often do not allow a region to have a clear view of their own initial situation. The initial situations of regions are not comparable to each other (see Heintel, 2010).

\footnotetext{
${ }^{5}$ https://de.wikipedia.org/wiki/Sankt-Florian-Prinzip (29.082017)
} 
Thesis: Confronting internal and external viewpoints, comparing facts and maintaining differentiating views on detailed questions can be emotionally relieving. Adding scientific inspection or accompaniment can be an additional basis. In the field of action, rationality and emotionality, appreciation and devaluation have a large role to play and should be examined critically. "Emigrants" can be a valuable resource by giving their "home" an opportunity to look in the mirror and see themselves for what they are.

\section{Field of action: Passive versus Possible}

Nature reserves, especially larger scale national parks and biosphere reserves are catalysts and project sites of multifunctional regional development with potential global operation. Their characteristics as "living and working landscapes" are spaces of possibility (see IUCN 2017) with a claim to sustainable development: "Large scale protected areas ... which are based on the principle of integration of people and nature, are becoming increasingly important in the global debate on sustainability" (VDN 2017: 14). They are spaces which offer use of resources for future generations, as general resource reservoirs, education or experimental space for sustainable regional development adapting climate change and adaptation strategies. They are spaces where a multitude of challenges can be addressed. Territorial protection can be a part of knowledge-based society, creative industry or an individualized life balance.

Viewing effect mechanisms in light of the work lifecycle of future nature reserves and their challenges brings forward the dimensions involved: society \& research, approaches, possibilities and limitations as well as good examples. Previous experiences, stakeholder arrangements and solution strategies and future oriented implementation scenarios play a central role in territorial protection and their policies. Beyond this scheme, the connection between chosen approaches of protected area policies and the actual challenges of megatrends and their cross points become clearer.

The literature distinguishes between 5 and 20 megatrends $^{6}$, depending on intended detail (see WBGU, 2011; Zukunftsinstitut, 2012; PwC, 2014). Since megatrends are versatile, complex and linked, their content intersections and impact directions are relevant. For example, in megatrends such as mobility, individualization, globalization, the content intersections are knowledge-based society, creative industry, life balance, social networks etc. (see MegatrendMap 2.0 in Zukunftsinstitut, 2012).

Megatrends in global and regional changes and their characteristics share intersections with territorial protections and therefore also tourism. They are defined by the public through the profile of protected areas (cf. territorial protection categories of the international protected area authority IUCN) and their expectations (e.g. regional development instruments with focus on tourism). The intersections reflect the megatrends and their content intersections, such as biodiversity, eco system services, acceptance and educational concerns, nature tourism, economic valorization of cultural landscapes etc.

Thesis: Large-scale protected areas have many useful intersections with megatrends and their content cross-sections. They offer rural and urban regions a variety of development possibilities within the mentioned multifunctional aspects. They can offer a sustainable contribution to turn passive spaces into "living or working landscapes".

\section{Field of action: Interchangeability versus Authenticity}

Numerous rural regions like the Neusiedlersee-Seewinkel-Region have high potential in the food sector. Cross-sector potentials provide added value. Reproduction or continuation of initiatives such as "Market of the World”, plant exchanges, integrating specific regional themes

\footnotetext{
${ }^{6}$ For fields of action for tourism and protected areas the following megatrends are of special relevance: Climate chan ge and energy transition, land-use change and threats to biodiversity, urbanization, mobility and spatial development, demographic change and migration, change of societal values and change of lifestyles.
} 
into school curriculums, cooperation with local news outlets or publishing a local cookbook are just a few examples of creative ideas that have emerged in rurally characterized regions.

Cross-sector networks can strengthen the regional economic environment. Regional product structures can be built up around a primary product such as a locally produced wine. By doing this, other approaches become relevant: Participation along the lines of "alliance of the willing", minimalism in the sense of strengthening what already exists, realism concerning the radius of perceptibility, personnel continuity, maintaining the authenticity of the projects and their sustainability, establishing a unique selling point and individuality, breaking down the anonymity of regional production chains.

In order to offer authenticity, the regional products need to undergo several refining stages to connect them to regional initial products. If this is successful in getting people to increase their demand for regional products, it also gives restaurant owners an opportunity to break out of the conventional purchasing groups. External inputs should be minimized in order to give the regional stakeholders a better sense of the consequences their actions carry locally. This also increases the readiness for them to take responsibility themselves.

Thesis: Regional products are instruments for introducing sustainable regional development. Regional development is a vital catalyst and stabilizer in formative stages of new cooperations and projects. It is the hub of networking, financial resource coordination and bundles interdisciplinary know-how. Regional products can be cross-sector instruments in strategic orientation for regions.

\section{Conclusion}

„Der Wegweiser weist den Weg, er geht ihn jedoch nicht mit." (A saying similar to: You can take a horse to water, but you can't make it drink.) This aphorism illustrates how well the fields of action in regional development are doing. "Concrete instructions", "precise steps", benchmarking or similar content are the results that politics and authorities want to see. Engaging somebody to show the way represents a longing, but following through on one's own is a process. Ultimately, those who want to make changes are also responsible in choosing the steps to do so.

The responsibility to identify proper steps is not always easy and certainly not trivial. Studies and support processes can aid in identifying feedback effects and possible fields of actions for regions. Generally, if a region is understood as a social system, it will not be possible to ramp up fields of action so much that the region will come undone. "Interventional research can be of valuable assistance. The 'outside view' allows for a certain degree of 'establishing trust' that can explain how to avoid self-hindering strategies." (Heintel, 2016: 204).

Demographic shifts, mobility and public transport, energy, regional basic services provisions, sustainable housing development, partnership between urban and rural and strengthening governance processes at regional level - these are the topics that are addressed in the Austrian Spatial Development Perspective 2011 and are of general regional interested for rural areas (ÖROK 2011).

The last budget review debates for the European financial framework have definitely emphasized one discourse from the Austrian perspective: It is all about funding, and not really about content. There is a strong focus on agriculture but not enough on future oriented themes such as research and development or other cross-sector topics that affect rural regions.

Let us look back to 1995. Austria had just joined the European Union - reason enough to rethink and restructure the national funding structures, reform cross-sector cooperation and become more eligible for funding from Brussel's perspective. All this was over 20 years ago. The conclusion: Policies for "the" rural area is not solely agricultural policy. It is a combination of economic, labor market, social and agricultural policies with a claim for diversification of rural areas. In parliamentary symposium of the Bundesrat in 2012 and even to this day, there is talk of "the" rural area, but this did not even exist back in 1995 (Kommunal, 2012). 
Rural areas are diverse and vary strongly structurally. Rural areas in the proximity of cities or large transport axis, mono-structural rural areas such as those dominated by tourism infrastructure, agriculture or forestry, or low density regions with economic development dynamics are all examples of this diversity. When talking about "the" rural areas, reference is usually being made to the structurally weak rural peripheral areas. Austria has a bit of it all. Not all rural areas are doing poorly, and not everywhere is the cultural landscape dominated by agriculture.

Different access levels and a variety of strategies are needed in rural policies. Catering to clients and (more) funding are not always the right answer to complex questions on topics of regional balance or competition.

However, rural peripheral areas are not homogenous and cannot be compared in all prerequisites. Demographic developments, family friendly environments, regional labor market and enhancing the attractiveness for migrants and returning emigrants vary significantly.

Currently, regional development is strongly influenced by the discussed tensions and fields of action. Regional development is not just new forms of digitalization (as discussed elsewhere), but by a multitudes of new features. Their various simultaneousness can be found in new forms of participation (e.g. housing), new neighborhoods, various types of spatial bonding, mobility (shared, sustainable), new working and living systems (using knowledge, EPUs, Sharing Economy) and new temporal models for everyday organization ("Time to share", marketplace of generations etc.) to name only a few.

\section{Academic references}

[1] Brown, D. L. \& Schucksmith, M. (2016). A new lens for examining rural change. European Countryside, 8(2), 183-188. DOI: 10.1515/euco-2016-0015.

[2] Crouch, C. (2008). Postdemokratie. Frankfurt am Main: Suhrkamp.

[3] Dax, T., Fidlschuster, L., Fischer, M., Hiess, H., Oedl-Wieser, T. \& Pfefferkorn, W. (2016). Regionen mit Bevölkerungsrückgang. Experten-Impulspapier zu regional- und raumordnungspolitischen Entwicklungs- und Anpassungsstrategien. Analyse und strategische Orientierung [research report]. Wien: Bundeskanzleiamt.

[4] Gagliardi, L. \& Percoco, M. (2017). The impact of European Cohesion Policy in urban and rural regions. Regional Studies 51(6), 857-868. DOI: 10.1080/00343404.2016.1179384.

[5] Hammer, T., Mose, I., Siegrist, D. \& Weixlbaumer, N., eds. (2016). Parks of the future. Protected Areas in Europe Challenging Regional and Global Change. München: Oekom.

[6] Heintel, M. (2005). Regionalmanagement in Österreich: Professionalisierung und Lernorientierung. Wien: Universität Wien.

[7] Heintel, M. (2006). Regional Governance: Modetrend oder brauchbare Theorie? Wirtschaft und Gesellschaft, 32(3), 345-367.

[8] Heintel, M. (2010). Wettbewerb der Regionen: der Vergleich macht Sie unsicher! Wirtschaft und Gesellschaft, 36(2), 257-266.

[9] Heintel, P. (2016). Interventionsforschung im Gemeindebereich. In Lerchster, R. \& Krainer, L., eds. Interventionsforschung Band 2. Anliegen, Potentiale und Grenzen transdisziplinärer Wissenschaft (pp. 179-207). Wiesbaden: Springer VS.

[10] Heintel, M., Speringer, M., Bauer, R. \& Schnelzer, J. (2016). Regionale Benachteiligung und Daseinsgrundvorsorge am Beispiel des Oberpinzgaus: Ein Widerspruch? Salzburg: Salzburger Institut für Raumordnung \& Wohnen.

[11] Humer, A. (2017). Linking polycentricity concepts to periphery: implications for an integrative Austrian strategic spatial planning practice. European Planning Studies 26(4), 635-652. DOI: 10.1080/09654313.2017.1403570. 
[12] Krainer, L. \& Lerchster, R., eds. (2012). Interventionsforschung Band 1. Paradigmen, Methoden, Reflexionen. Wiesbaden: Springer VS.

[13] Lerchster, R. \& Krainer, L., eds. (2016). Interventionsforschung Band 2. Anliegen, Potentiale und Grenzen transdisziplinärer Wissenschaft. Wiesbaden: Springer VS.

[14] Lukesch, R. (2016). Resiliente Regionen. Zur Intelligenz regionaler Handlungssysteme. In Wink, R. ed., Multidisziplinäre Perspektiven der Resilienzforschung (pp. 295-332). Wiesbaden: Springer.

[15] Mayerhofer, P. (2014). Demographischer Wandel als Herausforderung für Österreichs Regionalpolitik. Kleinräumige Perspektiven, ökonomische Konsequenzen, wirtschaftspolitische Handlungsoptionen. Mitteilungen der Österreichischen Geographischen Gesellschaft 156, 87-114.

[16] Nosek, Š. (2017). Territorial cohesion storylines in 2014-2020 Cohesion Policy. European Planning Studies, 25(12), 2157-2174. DOI: 10.1080/09654313.2017.1349079.

[17] Pike, A., Rodríguez-Pose, A. \& Tomaney, J. (2017). Shifting horizons in local and regional development. Regional Studies 51(1), 46-57. DOI: 10.1080/00343404.2016.1158802.

[18] Reiner, C., Gassler, H. \& Sardadvar, S. (2015). Österreichische Regionalentwicklung zwischen neuer Dynamik und alter Stabilität. In Politische Ökonomie Österreichs. Kontinuitäten und Veränderungen seit dem EU-Beitritt (pp. 156-173). Wien: Mandelbaum Verlag.

[19] Schindegger, F. (1999). Raum. Planung. Politik. Ein Handbuch zur Raumplanung in Österreich. Wien: Böhlau.

[20] Ward, N. \& Brown, D. L. (2009). Placing the Rural in Regional Development. Regional Studies 43(10), 1237-1244. DOI: 10.1080/00343400903234696.

[21] Wink, R., ed. (2016). Multidisziplinäre Perspektiven der Resilienzforschung. Wiesbaden: Springer.

[22] Zschiedrich, H. (2008). EU-Regionalpolitik im Spagat zwischen Wachstums- und Ausgleichszielen. Wirtschaft und Gesellschaft 34(4), 509-534.

Other sources

[23] Akademie für Raumforschung und Landesplanung (Hrsg.) (2016). Daseinsvorsorge und gleichwertige Lebensverhältnisse neu denken; Perspektiven und Handlungsfelder (Positionspapier aus der ARL 108). Hannover: ARL [https://shop.arlnet.de/media/direct/pdf/pospaper_108.pdf (27.08.2017)].

[24] BEIGEWUM (Hrsg.) (2015). Politische Ökonomie Österreichs. Kontinuitäten und Veränderungen seit dem EU-Beitritt (s. 156-173). Wien: Mandelbaum Verlag.

[25] European Union (2017). My Region, My Europe, Our Future. Seventh report on economic, social and territorial cohesion. Luxembourg: EU.

[26] Heintel, M. (2013). Leise Entsolidarisierung zwischen Stadt und Land. Die Presse, 26.04.2013, 30 .

[27] IUCN (International Union for Conservation of Nature) (Ed.) (2017). Guidelines for tourism partnerships and concessions for protected areas: generating sustainable revenues for conservation and development. Gland.

[28] Kammer für Arbeiter und Angestellte für Wien (Hrsg.) (2016). Wien Neu: Passende Strukturen für die wachsende Stadt (Stadtpunkte 18). Wien: AK.

[29] Kommunal (2012). Offizielles Organ des Österreichischen Gemeindebundes 11/2012 Wien: Österreichischer Gemeindebund 
[http://gemeindebund.at/images/uploads/downloads/2014/Publikationen/KOMMUNAL/2012 /KOMMUNAL_11-2012.pdf (27.08.2017)].

[30] OECD (2016), OECD Regional Outlook 2016: Productive Regions for Inclusive Societies, OECD Publishing, Paris [http://dx.doi.org/10.1787/9789264260245-en (04.01.2018)].

[31] OECD (2017). Multi-level Governance Reforms: Overview of OECD Country Experiences, OECD Publishing, Paris [http://dx.doi.org/10.1787/9789264272866-en (04.01.2018)].

[32] Österreichische Raumordnungskonferenz (ÖROK) (Hrsg.) (2011). Österreichisches Raumentwicklungskonzept ÖREK 2011 (Schriftenreihe Bd. 185). Wien: ÖROK.

[33] Österreichische Raumordnungskonferenz (ÖROK) (Hrsg.) (2015). Die regionale Handlungsebene stärken - Fachliche Empfehlungen und Materialband (Schriftenreihe Bd. 194). Wien: ÖROK.

[34] Österreichische Raumordnungskonferenz (ÖROK) (Hrsg.) (2016). Agenda Stadtregionen in Österreich. Empfehlungen der ÖREK-Partnerschaft „Kooperationsplattform Stadtregion“ und Materialienband (Schriftenreihe Bd. 198). Wien: ÖROK.

[35] Österreichischer Städtebund. Finanzausgleich.

[http://www.staedtebund.gv.at/themenfelder/finanzen/finanzausgleich.html (29.08.2017)].

[36] Parlament (2012). ExpertInnen und Politik einig: Ländlicher Raum braucht Arbeitsplätze. Enquete des Bundesrats (Parlamentskorrespondenz Nr. 758). Wien [https://www.parlament.gv.at/PAKT/PR/JAHR_2012/PK0758/ (27.03.2017)].

[37] PricewaterhouseCoopers (PwC) (2014). Anticipating problems, finding solutions. Global annual Review 2014 [http://www.pwc.com/gx/en/global-annual-review/download.jhtml (27.08.2017)].

[38] Republik Österreich (Hrsg.) (2013). Arbeitsprogramm der österreichischen Bundesregierung 2013-2018. Wien: Bundeskanzleramt.

[39] VDN (Verband Deutscher Naturparke) (Ed.) (2017). Living Landscapes. Europe's Nature, Regional, and Landscape Parks - model regions for the sustainable development of rural areas. Bonn

[40] Wissenschaftlicher Beirat der Bundesregierung Globale Umweltveränderungen (WBGU) (2011). Factsheet globale Megatrends [http://www.wbgu.de/factsheets/factsheet-32011 (27.08.2017)].

[41] Zukunftsinstitut (2012). Megatrend Dokumentation

[https://www.zukunftsinstitut.de/artikel/megatrend-dokumentation (27.08.2017)]. 